\title{
Interrelation of DNA Replication, Specific Growth Rate and Growth Temperature in the Sensitivity of Escherichia coli to Cold Shock
}

\author{
By PETER GILBERT, ${ }^{1}$ NOEL A. DICKINSON ${ }^{1}$ AND \\ MICHAEL R. W. BROWN ${ }^{2}$ \\ ${ }^{1}$ Department of Pharmacy, University of Manchester, Manchester M13 9PL \\ ${ }^{2}$ Department of Pharmacy, University of Aston in Birmingham, Gosta Green, \\ Birmingham B4 7ET
}

(Received 2 March 1979)

\begin{abstract}
Escherichia coli W3110 was grown in a chemostat under conditions of carbon limitation at various temperatures and specific growth rates $(\mu)$. Exponential survivor-time curves following cold osmotic shock were biphasic. These could be described by the sum of two exponential functions representing the survival of sensitive and resistant fractions of the population where the size of the sensitive fraction was directly proportional to $\mu$. Decimal reduction times for the more resistant fraction were unaffected by $\mu$ yet decreased with increasing growth temperature.

Sensitivity to cold shock was evaluated for an $E$. coli CR34 mutant, temperaturesensitive in initiation of DNA replication. When grown in the chemostat at the non-restrictive temperature $\left(30^{\circ} \mathrm{C}\right)$ sensitivity was directly proportional to $\mu$. Following a rise in the incubation temperature to $42^{\circ} \mathrm{C}$, sensitivity decreased markedly and reached a minimum 45 to 60 min after the temperature increase. Sensitivity of the $E$. coli mutant grown at $30^{\circ} \mathrm{C}$ and raised to $42{ }^{\circ} \mathrm{C}$ for $1 \mathrm{~h}$ was low and relatively unaffected by growth rate.
\end{abstract}

\section{INTRODUCTION}

Injury or death of micro-organisms following their subjection to rapid chilling is termed cold shock (MacLeod \& Calcott, 1976). Although sensitivity to cold shock has been demonstrated for some diverse groups of micro-organisms, Gram-negative bacteria are generally regarded as being particularly susceptible (Brown, 1971; Gorrill \& McNeil, 1960). The primary events leading to cold shock-mediated death in Gram-negative bacteria are thought to involve disorganization of the outer (Brown, 1975) and cytoplasmic membranes (Meynell, 1958; Strange \& Dark, 1962; Leder, 1972), in the latter case through phase changes of the membrane's phospholipids (Farrel \& Rose, 1968). This leads to a decreased osmoregulatory capability of the cells (Strange \& Ness, 1963; Adikari, 1975). Autodegradation of nucleic acid polymer (Smeaton \& Elliott, 1967) and inactivation of DNA ligase (Sato \& Takahashi, 1970) have also been implicated.

Phenotypic variation in cold shock sensitivity has been widely reported. Batch culture sensitivity is greatest during the exponential growth phase (Hegarty \& Weeks, 1940; Adhikari, 1975), decreases with decreasing growth temperature (Ring, 1965; Farrel \& Rose, 1968 ) and may vary with the complexity of the medium (Farrel \& Rose, 1968; Meynell, 1958). Recent reports (Green, 1978; Kenward \& Brown, 1978) have demonstrated a direct relationship between sensitivity to cold shock and the specific growth rate $(\mu)$ of Vibrio cholerae and Pseudomonas aeruginosa and suggest that this may be due, in part, to sensitization at particular points in the cell cycle of these organisms. 


\section{METHODS}

Organisms and chemicals. Escherichia coli K12 W3110 and E. coli CR34 E177, which is temperaturesensitive in initiation of DNA replication (Wechsler \& Gross, 1971), were used throughout. Stock cultures were maintained on nutrient agar slants at room temperature after overnight incubation at $30^{\circ} \mathrm{C}$. All chemicals were of the purest grade available (BDH).

Growth conditions. Escherichia coli cultures were grown in $50 \mathrm{ml}$ chemostats (Gilbert \& Stuart, 1977) at $25,30,35$ and $42{ }^{\circ} \mathrm{C}$ at dilution rates of between 0.05 and $0.45 \mathrm{~h}^{-1}$ in a minimal salts carbon-limited medium (Gilbert \& Brown, 1978), supplemented in the case of E. coli CR34 E177 with ( $20 \mu \mathrm{g} \mathrm{ml}^{-1}$ each) thiamin, thymine, leucine and threonine. To check for reversion of the CR34 E177 strain, replica plates were made from the chemostat culture and incubated at 30 and $42{ }^{\circ} \mathrm{C}$. Steady-state conditions were assumed after five volume changes had occurred. Temperature shifts were made after a steady-state had been achieved.

Sensitivity to cold osmotic shock. Cultures were taken directly from the chemostat (approx. $1 \times 10^{9}$ cells $\mathrm{ml}^{-1}$ ), diluted 100 -fold into $50 \mathrm{ml}$ distilled water, pre-cooled and held on ice. Viable counts were made at suitable time intervals by serially diluting the bacteria in water and spreading on nutrient agar plates. Plates were incubated at $30^{\circ} \mathrm{C}$ for 18 to $24 \mathrm{~h}$ and results are expressed as percentage survival with respect to the control suspension similarly diluted in distilled water and held at the incubation temperature of the original culture.

Analysis of data. Data describing the survival of E. coli following cold shock were subjected to numerical analysis using a CDC 7600 computer and non-linear least squares regression analysis (Metzler et al., 1974).

\section{RESULTS}

Following cold shock at $0{ }^{\circ} \mathrm{C}$ for $60 \mathrm{~min}$, the survival of E. coli W3110 grown at 30 and $42{ }^{\circ} \mathrm{C}$ was found to be proportional to $\mu$. The slopes of the graphs were similar but the intercept value was lower for the higher growth temperature (Fig. 1). For bacterial suspensions grown in the chemostat at $30^{\circ} \mathrm{C}$ and raised to $42^{\circ} \mathrm{C} 1 \mathrm{~h}$ before cold shock, sensitivity was proportional to $\mu$, but the slope of this relationship was greater than that for the other systems.

Time-survivor curves for all systems except the E. coli mutant were biphasic (Fig. 2). The sensitive phase terminated within 20 to 30 min of treatment and the degree of sensitivity of this phase and its size appeared to increase with increasing growth rate. Decimal reduction times for the second and more resistant phase were unaffected by growth rate yet decreased with increasing growth temperature (Fig. $2 c$ ). The data sets for growth at 30 and $42^{\circ} \mathrm{C}$ (Fig. $2 a, b$ ) were subjected to numerical analysis. The survival data could be described by the sum of two exponential functions representing the survival of sensitive and resistant fractions of the population. The fraction with increased sensitivity to cold shock was found to be directly proportional to $\mu$, irrespective of growth temperature (Fig. 3). This sensitive fraction could be alternatively described as a time(DT), constant for individual bacteria with respect to $\mu$, during each division cycle when the organisms possessed an increased sensitivity to cold shock. DT is therefore the mean sensitization time for individual organisms within the culture. Time-survivor curves for each temperature set could thus be combined and described by equation (1).

$$
p=\frac{\mathrm{DT}}{\mathrm{GT}} \exp \left(-k_{\mathrm{SF}} t\right)+\left(1-\frac{\mathrm{DT}}{\mathrm{GT}}\right) \exp \left(-k_{\mathrm{RF}} t\right)
$$

where $p$ is the surviving fraction at time $t$, GT is the generation time (min), and $k_{\mathrm{SF}}$ and $k_{\mathrm{RF}}$ are rate constants for the death of the sensitive and resistant fractions, respectively. A simultaneous non-linear least squares regression analysis was conducted to determine the best estimates of $\mathrm{DT}, k_{\mathrm{PF}}$ and $k_{\mathrm{RF}}$ separately for each survivor curve and for combined data for the two growth temperatures. Goodness of fit for the combined data and for analysis of individual survivor curves were not significantly different $[F=1.369$ and 0.47 (critical value $=2 \cdot 51$ ) for cultures grown at 30 and $42{ }^{\circ} \mathrm{C}$, respectively]. The lines in Fig. $2 a, b$ are the computed best fit estimates based on equation (1) for each temperature set. Values of DT were $49 \cdot 2 \pm 2 \cdot 8 \mathrm{~min}$ and $42 \cdot 8 \pm 4 \cdot 4 \mathrm{~min}$ for cultures grown at 30 and $42{ }^{\circ} \mathrm{C}$, 


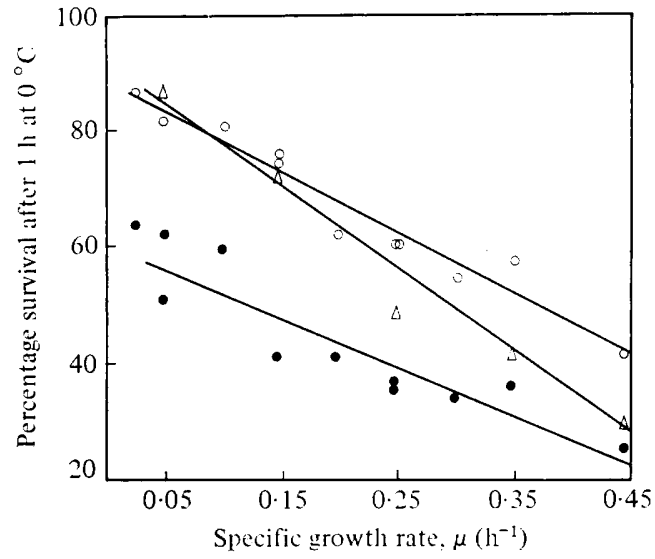

Fig. 1. Influence of specific growth rate and growth temperature on the survival of Escherichia coli W3110 following cold shock treatment for $1 \mathrm{~h}$. Bacteria grown at $30^{\circ} \mathrm{C}(\mathrm{O})$, at $42{ }^{\circ} \mathrm{C}(\mathrm{O})$ or at $30^{\circ} \mathrm{C}$ followed by $1 \mathrm{~h}$ at $42{ }^{\circ} \mathrm{C}$ prior to cold shock $(\triangle)$.

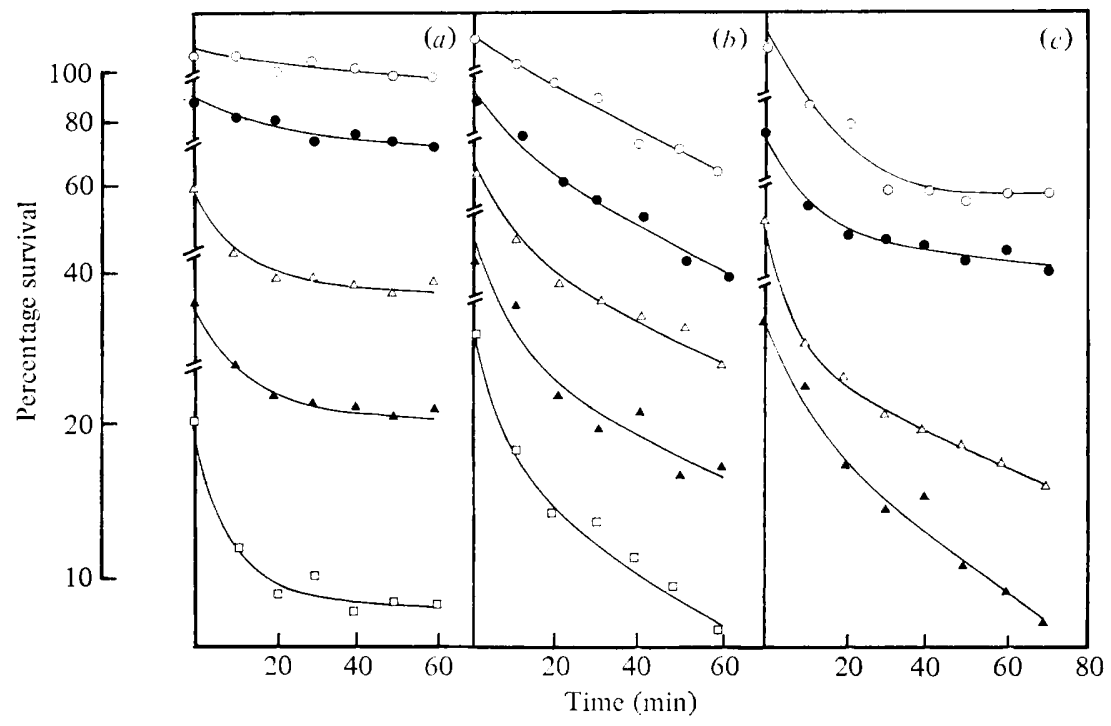

Fig. 2. Time-survivor curves following cold shock for Escherichia coli W3110 grown at various temperatures and dilution rates. $(a, b)$ Bacteria grown at $30^{\circ} \mathrm{C}(a)$ or at $42{ }^{\circ} \mathrm{C}(b)$ at $D=0.05 \mathrm{~h}^{-1}$ (O), $0.15 \mathrm{~h}^{-1}(O), 0.25 \mathrm{~h}^{-1}(\triangle), 0.35 \mathrm{~h}^{-1}(\Delta)$ or $0.45 \mathrm{~h}^{-1}(\square)$; the curves $(\longrightarrow)$ are the computed least mean squares fit based on equation (1) for each temperature set. (c) Bacteria grown at $D=$ $0 \cdot 35 \mathrm{~h}^{-1}$ at $25^{\circ} \mathrm{C}(\mathrm{O}), 30^{\circ} \mathrm{C}(\mathrm{O}), 35^{\circ} \mathrm{C}(\triangle)$ or $42^{\circ} \mathrm{C}(\Delta)$.

respectively. $k_{\mathrm{SF}}$ was independent of growth temperature $\left(k_{\mathrm{SF}}=0 \cdot 149 \pm 0 \cdot 023\right.$ and $0.114 \pm 0.023$ for 30 and $42{ }^{\circ} \mathrm{C}$, respectively) and corresponded to a decimal reduction time $\left(\mathrm{LT}_{90}\right)$ of 15 to $20 \mathrm{~min}$. $k_{\mathrm{RF}}$ was found to increase with increasing growth temperature $\left[k_{\mathrm{RF}}=0.0013 \pm 0.0005\left(\mathrm{LT}_{90}=1771 \mathrm{~min}\right)\right.$ and $0.011 \pm 0.0008\left(\mathrm{LT}_{90}=209 \mathrm{~min}\right)$ for growth at 30 and $42{ }^{\circ} \mathrm{C}$, respectively].

Sensitivity to cold shock was also examined for E. coli CR34 E177, which is temperaturesensitive in initiation of DNA replication. When grown at the non-restrictive temperature $\left(30^{\circ} \mathrm{C}\right)$, sensitivity to cold shock was proportional to growth rate. However, when the cold shock was preceded by growth for $1 \mathrm{~h}$ at the restrictive temperature $\left(42^{\circ} \mathrm{C}\right)$, sensitivity was 


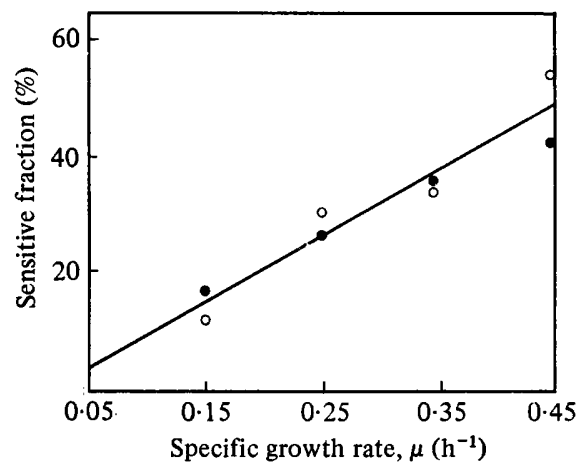

Fig. 3. Relationship between the sensitive fraction of the population and specific growth rate.

Bacteria grown at $30^{\circ} \mathrm{C}(\mathrm{O})$ or at $42^{\circ} \mathrm{C}(\bullet)$.

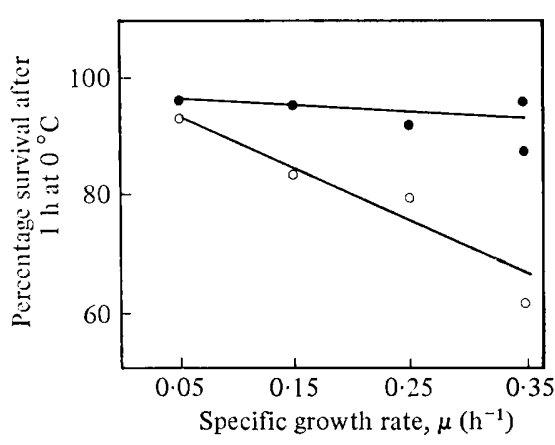

Fig. 4

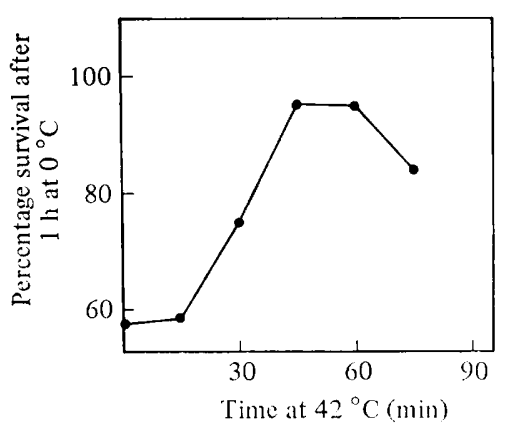

Fig. 5

Fig. 4. Influence of specific growth rate and growth temperature on the survival of Escherichia coli CR34 E177 following cold shock treatment for $1 \mathrm{~h}$. Bacteria grown at $30^{\circ} \mathrm{C}(\mathrm{O})$ or at $30^{\circ} \mathrm{C}$ followed by $1 \mathrm{~h}$ at $42^{\circ} \mathrm{C}$ prior to cold shock (O).

Fig. 5. Development of resistance to cold shock by E. coli CR34 E177 after raising the growth temperature from 30 to $42{ }^{\circ} \mathrm{C}\left(\mu=0.35 \mathrm{~h}^{-1}\right)$.

low and relatively unaffected by growth rate (Fig. 4). Sensitivity was assessed at intervals after raising the growth temperature from 30 to $42{ }^{\circ} \mathrm{C}$ for cultures grown at $D=0.35 \mathrm{~h}^{-1}$ (Fig. 5). Sensitivity decreased markedly and reached a minimum 45 to $60 \mathrm{~min}$ after the temperature increase.

\section{DISCUSSION}

Unlike the experimental systems of Kenward \& Brown (1978) and Green (1978), the bacteria in this study were subjected not only to cold, but also to osmotic shock. Viability of the control suspension, osmotically shocked at the culture growth temperature, was not adversely affected, but the possiblity of synergism between cold and osmotic shock cannot be excluded. However, in accordance with the observations of Kenward \& Brown (1978) and Green (1978) for Pseudomonas aeruginosa and Vibrio cholerae, respectively, the sensitivity of $E$. coli to cold shock was directly related to $\mu$ (Fig. 1). It was proposed by these workers that sensitivity to cold shock might be due to sensitization at particular points in the cell cycle (Kenward \& Brown, 1978).

Time-survivor curves (Fig. 2) suggested that the cell population was composed of two fractions, slopes of the resistant phase being unaffected by $\mu$ yet increasing with growth temperature, and the size of the sensitive fraction being directly proportional to $\mu$ (Fig. 3 ). Numerical analysis revealed that the survival data for each incubation temperature could 
be described by equation (1). Sensitivity of the sensitive fraction was unaffected by its growth temperature, whereas the sensitivity of the remainder increased approximately 10 -fold as the temperature was increased from 30 to $42{ }^{\circ} \mathrm{C}$. Previous workers have also reported that cold shock sensitivity increases with increasing growth temperature (Farrel \& Rose, 1968; Adhikari, 1975; Ring, 1965), and suggested that this is due to increases in the levels of saturation of the envelope fatty acids at the higher temperatures. At slow rates of growth, sensitivity of cells grown at $30^{\circ} \mathrm{C}$ and raised to $42{ }^{\circ} \mathrm{C} 1 \mathrm{~h}$ prior to cold shock approximated to that for the $30^{\circ} \mathrm{C}$ culture and approached that of the $42{ }^{\circ} \mathrm{C}$ culture as $\mu$ was increased (Fig. 1). The linearity of this relationship suggested that the time taken by cells to adapt to growth at the higher temperatures was dependent on $\mu$, possibly representing a constant fraction of the cell cycle. Therefore $1 \mathrm{~h}$ growth at $42{ }^{\circ} \mathrm{C}$ for cultures with low $\mu$ resulted in only partial adaptation, whilst as $\mu$ increased $1 \mathrm{~h}$ represented a greater fraction of the generation time and the adaptation was able to proceed further.

Escherichia coli CR34 E177 (Wechsler \& Gross, 1971) is a mutant which is temperaturesensitive in initiation of DNA replication. Growth at the restrictive temperature $\left(42{ }^{\circ} \mathrm{C}\right)$ prevents initiation of new rounds of DNA replication, allows completion of those already underway and does not significantly affect rates of protein synthesis (Wechsler \& Gross, 1971). Following a rise in the incubation temperature from 30 to $42{ }^{\circ} \mathrm{C}$, cold shock sensitivity decreased markedly, and reached a minimum after 45 to $60 \mathrm{~min}$ (Fig. 5). This time approximated to that necessary to allow completion of DNA replication initiated prior to the temperature increase and suggested that DNA replication or some related event increases sensitivity of the cells to cold shock. The small increase in sensitivity after $1 \mathrm{~h}$ incubation at $42^{\circ} \mathrm{C}$ (Fig. 5) possibly reflected adaptation of the culture to the higher growth temperature, with the consequent increase in $k_{\mathrm{RF}}$.

Kenward \& Brown (1978) report biphasic time-survivor curves for cold-shocked $P$. aeruginosa, where the fraction of the culture sensitive to cold shock is directly related to $\mu$. They suggested that bacteria might become sensitized during cell division or some related event such as constriction. The sensitive fractions of these cultures were, however, also equivalent to that fraction replicating DNA, estimated on the basis of a $45 \mathrm{~min}$ period of replication during each cell cycle (M. A. Kenward \& M. R. W. Brown, unpublished results). Similarly, the variation in cold shock sensivity with $\mu$ reported by Green (1978) approxi* mates to that expected if the sensitizing event were DNA replication rather than constriction.

Our data suggests that at least two independent mechanisms are involved in the cold shock-mediated death of Gram-negative bacteria. One of these is independent of incubation temperature and involves sensitization of the bacteria to cold shock for part of their cell cycle, possibly during DNA replication. The second is dependent upon the growth temperature, probably involves the whole population and is independent of $\mu$. Increases in cold shock sensitivity with increasing growth rate at constant temperature might therefore reflect the fraction of the population undergoing DNA replication or some related event, rather than fundamental changes in the nature of the individual cells.

We are grateful to Dr B. J. Bachmann for providing the E. coli CR34 E177 mutant.

\section{REFERENCES}

ADHIKARI, P. C. (1975). Sensitivity of cholera and El Tor vibrios to cold shock. Journal of General Microbiology 87, 163-166.

Brown, M. R. W. (1971). Inhibition and destruction of Pseudomonas aeruginosa. In Inhibition and Destruction of the Microbial Cell, p. 358. Edited by W. B. Hugo. London: Academic Press.
Brown, M. R. W. (1975). The role of the cell envelope in resistance. In Resistance of Pseudomonas aeruginosa, p. 97. Edited by M. R.W. Brown. London: Wiley.

FARREL, J. \& Rose, A. H. (1968). Cold shock in a mesophilic and psychrophilic pseudomonad. Journal of General Microbiology 50, 429-439. 
GILBERT, P. \& BRowN, M. R. W. (1978). Effect of R-plasmid RP1 and nutrient depletion on the gross cellular composition of Escherichia coli and its resistance to some uncoupling phenols. Journal of Bacteriology 133, 1062-1065.

Gilbert, P. \& StUART, A. (1977). Small-scale chemostat for the growth of thermophilic and mesophilic microorganisms. Laboratory Practice 26, 627-628.

GoRrILL, R. H. \& MCNeIL, E. M. (1960). The effect of cold diluent on the viable count of Pseudomonas pyocyanea. Journal of General Microbiology 22, 437-442.

GreEN, J. A. (1978). The effects of nutrient limitation and growth rate in the chemostat on the sensitivity of Vibrio cholerae to cold shock. FEMS Microbiology Letters 4, 217-219.

HEGARTY, C. P. \& WEEKS, O. B. (1940). Sensitivity of Escherichia coli to cold shock during logarithmic phase growth. Journal of Bacteriology 39, 475-484.

KenWard, M. A. \& Brown, M. R. W. (1978). Relation between growth rate and sensitivity to cold shock of Pseudomonas aeruginosa. FEMS Microbiology Letters 3, 17-19.

LEDER, I. G. (1972). Interrelated effects of cold shock and osmotic pressure on the permeability of the Escherichia coli membrane to permease accumulated substrates. Journal of Bacteriology 111, 211-219.

MacLeod, R. A. \& Calcott, P. H. (1976). Cold shock and freezing damage to microbes. Symposia of the Society for General Microbiology 26, 81-109.
Metzler, C. M., Elfring, G. L. \& McEwen, A. J. (1974). A User's Manual for NONLIN and Associated Programmes. Kalamazoo, Michigan: The Upjohn Company.

MEYNELl, G. G. (1958). The effect of sudden chilling on Escherichia coli. Journal of General Microbiology 19, 380-389.

RING, K. (1965). The effect of low temperatures on permeability in Streptomyces hydrogenans. Biochemical and Biophysical Research Communications 19, 579-581.

Sato, M. \& Takahashi, H. (1970). Cold shock of bacteria. IV. Involvement of DNA ligase reaction in recovery of Escherichia coli from cold shock. Journal of General and Applied Microbiology 16, 279-290.

Smeaton, J. R. \& Elliott, W. H. (1967). Selective release of ribonuclease-inhibitor from Bacillus subtilis cells by cold shock treatment. Biochemical and Biophysical Research Communications 26, 75-81.

Strange, R. E. \& Dark, F. A. (1962). Effect of chilling on Aerobacter aerogenes in aqueous suspension. Journal of General Microbiology 29, 719-730.

Strange, R. E. \& Ness, A. G. (1963). Effect of chilling on bacteria in aqueous suspension. Nature, London 197, 819-821.

WeCHSLER, J. A. \& GROss, J. D. (1971). Escherichia coli mutants temperature-sensitive for DNA synthesis. Molecular and General Genetics 113, 273-284. 